\title{
The performance of Chlorella vulgaris growth on mass-scale cultivation
}

\author{
Dini Alvateha ${ }^{1}$, Siska Falentina ${ }^{2}$, Rarasrum Dyah Kasitowati ${ }^{3}$, Sutianto Pratama \\ Suherman ${ }^{4}$, Luthfiana Aprilianita Sari ${ }^{5}$, Sulastri Arsad ${ }^{* 6,7,8}$ \\ ${ }^{1}$ Undergraduate student of the Study Program of Aquatic Resources Management, Faculty of Fisheries and Marine \\ Sciences, Universitas Brawijaya, Jl. Veteran Malang 65145, Indonesia \\ ${ }^{2}$ The Technical Implementation Unit of Freshwater and Brackish Water Aquaculture, Situbondo, Jl. Pantai Pathek \\ Situbondo 68351, Indonesia \\ ${ }^{3}$ Study Program of Marine Science, Faculty of Fisheries and Marine Sciences, Universitas Brawijaya, Jl. Veteran Malang \\ 65145, Indonesia \\ ${ }^{4}$ Department of Aquaculture, Fisheries and Marine Science Faculty, Gorontalo State University, Gorontalo 96128, \\ Indonesia \\ ${ }^{5}$ Department of Fish Health Management and Aquaculture, Faculty of Fisheries and Marine Universitas Airlangga, \\ Surabaya 60115, Indonesia \\ ${ }^{6}$ Study Program of Aquatic Resources Management, Faculty of Fisheries and Marine Sciences, Universitas Brawijaya, Jl. \\ Veteran Malang 65145, Indonesia \\ ${ }^{7}$ AquaRES Research Group, Faculty of Fisheries and Marine Science, Universitas Brawijaya, Jl. Veteran Malang 65145, \\ Indonesia \\ ${ }^{8}$ MicroBase Research Group, Postgraduate Department, Universitas Brawijaya, Jl. Veteran Malang 65145, Indonesia \\ * Corresponding author: sulastriarsad@ub.ac.id
}

\section{ARTICLE INFO}

\section{Keywords:}

Cultivation techniques;

Phytoplankton; Water quality

\section{How to cite:}

Alvateha, D., Falentina, S., Kasitowati, R. D.,

Suherman, S. P., Sari, L. A., \& Arsad, S. (2020). The performance of Chlorella vulgaris growth on massscale cultivation. Tomini Journal of Aquatic Science, $1(2), 45-54$.

\begin{abstract}
Phytoplankton plays an important role, including as a primary producer, natural food, bioindicator, and water pollution treatment. For this reason, their availability needs to be managed, one of which is through cultivation. The purpose of this study was to analyze the mass scale cultivation of Chlorella vulgaris. The research was conducted at the Technical Implementation Unit of Freshwater and Brackish Water Aquaculture, Situbondo, using a descriptive method. The data were analyzed statistically using MS. Excel 2016 software, and a multiple linear regression test was carried out to determine the effect of water quality parameters on the growth of $C$. vulgaris using the SPSS 16.0 application. The cultivation process started from strain preparation, water and tank preparation, culture media preparation, inoculation, fertilization, and harvesting. The initial density of C. vulgaris used was $145 \times 10^{4}$ cell. $\mathrm{mL}^{-1}$ in tank 1 and $188 \times 10^{4}$ cell. $\mathrm{mL}^{-1}$ in tank 2 . The results showed that the cell density value of $C$. vulgaris increased every day until it entered the exponential phase, that is on the $4^{\text {th }}$ day of the culture activity, which was $507 \times 10^{4}$ in tank 1 and $536 \times 10^{4}$ cell. $\mathrm{mL}^{-1}$ in tank 2 . Furthermore, the value of water quality parameters that affected the growth of $C$. vulgaris in tank 1 and tank 2 was dissolved oxygen of $4.82-6.97 \mathrm{mg}$. $\mathrm{L}^{-1}, \mathrm{pH} 8.2-9.1$, transparency of $20-45 \mathrm{~cm}$, temperature was $26.8-28.2{ }^{\circ} \mathrm{C}$, nitrate of $0.10-0.50 \mathrm{mg} . \mathrm{L}^{-1}$, phosphate of $0.75-2 \mathrm{mg}^{-1}$, and salinity of $30-39 \mathrm{ppt}$.
\end{abstract}




\section{INTRODUCTION}

Phytoplankton is microorganisms that drift in the waters and their movements are influenced by currents. Phytoplankton act as a primary producer in the food chain in waters because they can carry out a photosynthetic process that is able to convert inorganic compounds into organic compounds by utilizing sunlight as an energy source, which is then utilized by organisms in the waters (Winder \& Sommer, 2012; Salman et al., 2013; Persada et al., 2019). Phytoplankton plays an important role in aquatic ecosystems, such as a primary producer, natural food, bioindicators, and water pollution treatment. In addition, the high fat content of several microalgae species is being investigated for biodiesel production (Romdhane et al., 2013). The utilization of microalgae can also reduce greenhouse gas emissions because, in general, microalgae require a source of carbon dioxide to reproduce (Hadiyanto \& Azim, 2012). Phytoplankton in the limited nature is the basis for the cultivation which serve to provide huge amounts of phytoplankton. Phytoplankton cultivation can be carried out at various scales according to the needs, including laboratory (Arsad et al, 2019), semi-mass, and mass-scales.

Mass-scale cultivation was carried out in ponds or concrete tanks with brackish water media. The cultivation of $C$. vulgaris was carried out in several stages, from preparation to harvesting. Moreover, water quality monitoring was done in the cultivation of $C$. vulgaris in this study. The understanding on what factors affect the growth of $C$. vulgaris is also very important, so that culture activities can run optimally (Chia et al., 2013).

In this study, C. vulgaris were used as natural food for Rotifers (B. plicatilis). This statement is in accordance to Novianti et al. (2017); Kandi (2018); Prayogo and Arifin (2015) stating that $C$. vulgaris can be used as natural food for zooplankton such as Rotifers (B. plicatilis). This species contains $51-58 \%$ protein, $12-26 \%$ carbohydrates, $2-22 \%$ fat, and $4-6 \%$ nucleic acids (Becker, 1994). This study aimed to analyze the cultivation management of $C$. vulgaris on a mass-scale and to analyze water quality parameters that affect the growth this species.

\section{MATERIALS AND METHODS}

Site and time. The research was conducted at the Technical Implementation Unit of Freshwater and Brackish Water Aquaculture, Situbondo, located on Pantai Pathek street, Gelung Selatan, Panarukan District, Situbondo Regency, East Java 68351 (70 38'35.6 "S $113^{\circ}$ 59'21.6" E) on July 13, 2020 - August 12, 2020. The geographic location of the research site can be seen in Figure 1.
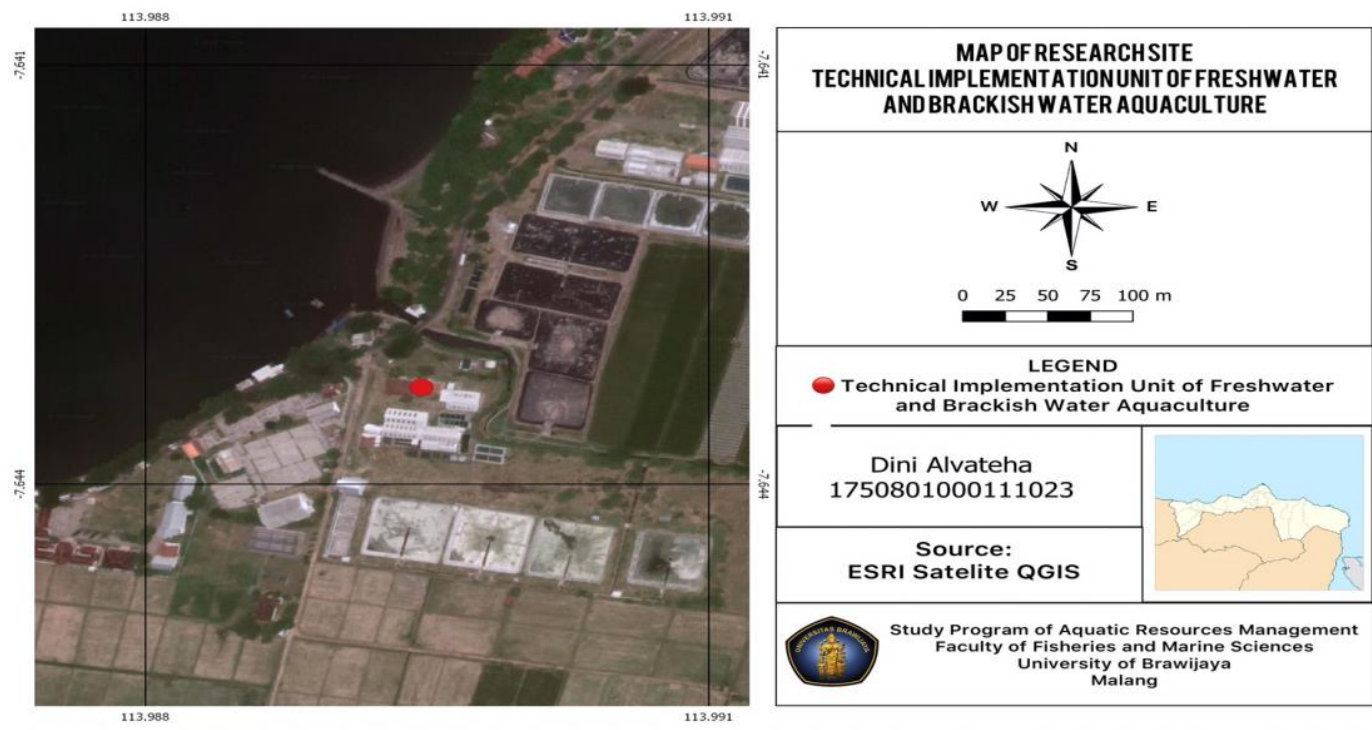

Figure 1. Map of Research Site. 
Data collection technique. The parameters measured in this study included the main and supporting parameters. The main parameter was the density of $C$. vulgaris to see the dynamics of their growth. The supporting parameter was water quality, which included dissolved oxygen, $\mathrm{pH}$, transparency, temperature, nitrate, phosphate, and salinity. The measuring instruments used included density (cell. $\mathrm{mL}^{-1}$, Neubauer hemocytometer), dissolved oxygen (mg. L-1, YSI 550A DO Meter), $\mathrm{pH}$ ( $\mathrm{pH}$ Meter pHep by HANNA), transparency (cm, Secchi disk) (Maresi et al., 2015), temperature ( ${ }^{\circ} \mathrm{C}$, YSI 550A DO Meter), nitrate (mg. $\mathrm{L}^{-1}$, Merck KGaA nitrate test kit), phosphate (mg. L-1, Merck KGaA phosphate test kit), and salinity (ppt, ATAGO refractometer).

Research method. The method used in this research was a descriptive method. The primary data were obtained directly through observation and documentation. The tanks used in the study were concrete tanks measuring $3 \times 4 \times 1.2 \mathrm{~m}^{3}$ or having a volume of 12 tons (Figure 2 ), yet for culture activities, only 9 tons were filled in 2 tanks, namely tank 1 and tank 2, for the comparison purposes. Meanwhile, water quality parameters consisted of physical and chemical parameters. Physical parameters consisted of temperature and transparency, while chemical parameters consisted of dissolved oxygen, $\mathrm{pH}$, nitrate, phosphate, and salinity. This is in accordance with the opinion of Boroh et al. (2019) and Daliry et al. (2017) that the growth of phytoplankton in culture media is strongly influenced by physical and chemical parameters of water quality, including the availability of nutrients in the form of nitrates and phosphates as well as temperature, salinity, dissolved oxygen, $\mathrm{pH}$, transparency.

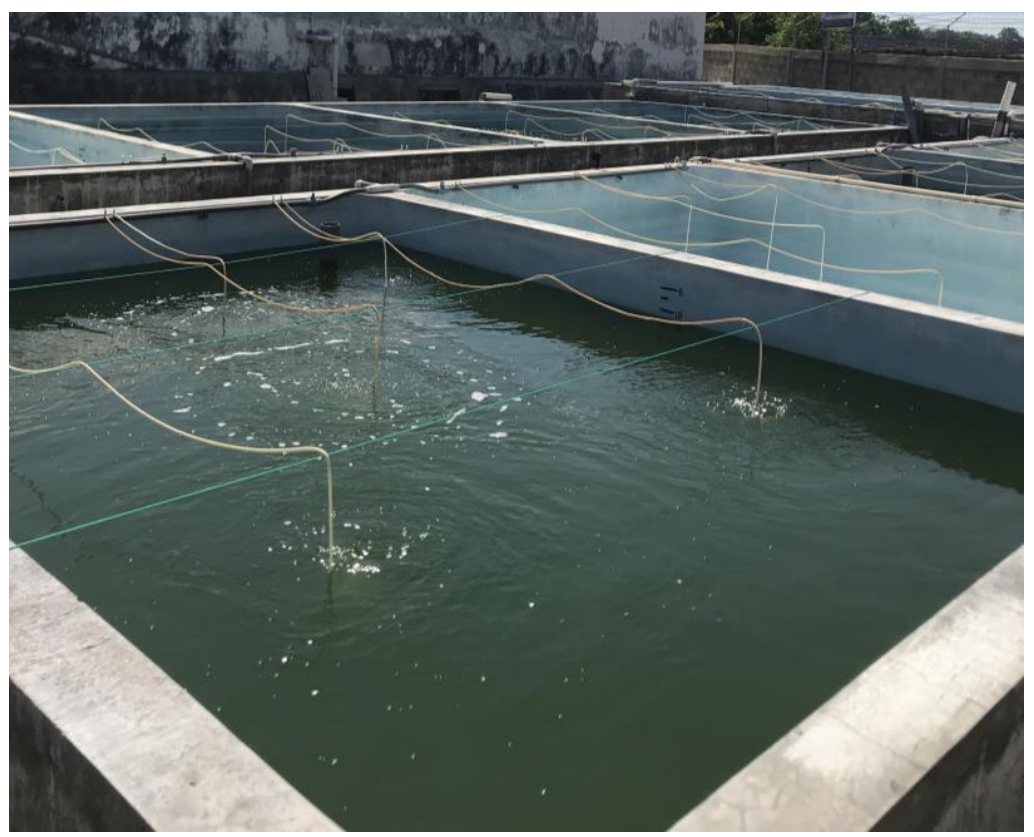

Figure 2. Cultivation tanks of C. vulgaris.

Cultivation stages. The cultivation stages of $C$. vulgaris consisted of strain preparation, water preparation, tank and culture media preparation, fertilizer production, inoculation and fertilization, and harvesting. The strain used for the culture of $C$. vulgaris came from the Technical Implementation Unit of Freshwater and Brackish Water Aquaculture, Situbondo, which entered the lag phase. The water used for the culture of $C$. vulgaris was seawater that had been treated or sterilized in a $4 \times 5 \times 2 \mathrm{~m}^{3}$ tank, which was then given $\mathrm{Hi}$ chlon with a concentration of $10 \mathrm{ppm}$ as much as 400 grams to kill bacteria and let stand for 5 hours. Moreover, it was added with Na-thiosulfate with a concentration of $5 \mathrm{ppm}$ as much as 200 grams for neutralization and waited on for 2 hours before a chlorine test was carried out by dropping OTO (ortholidine) on the sample water to determine whether the water was neutral or not, and then the color change was observed. The sample water that changed color to yellow indicated that the water was not yet neutral, but if the water remained clear, it indicated that the water was neutral. The dry tank was then filled with seawater from the 70 
$\mathrm{cm}$ seawater treatment reservoir. Aeration was used during the culture process so that $C$. vulgaris cells could obtain nutrition evenly because of the circulation of water in the culture tank. Moreover, the fertilizer used consisted of three types, namely 100 grams of urea, 50 grams of ZA fertilizer, and 100 grams of TSP fertilizer. The culture tank that had been filled with culture media were then filled with $C$. vulgaris strain as high as $20-30 \mathrm{~cm}$ so that the volume of water in the culture tank became $90-100 \mathrm{~cm}$. The final step was harvesting, which was done by pumping them out using a submersible pump before flowing them through a hose connected to the Rotifera ( $B$. plicatilis) culture tank. Harvesting was carried out partially, that is, when C. vulgaris entered an exponential phase, which was on the $4^{\text {th }}$ day of culture activity. Meanwhile, the data collection was carried out for 7 days or until $C$. vulgaris entered the death phase.

Growth of C. vulgaris. Phytoplankton growth was observed every day by calculating cell density using a Neubauer hemocytometer (Salgueiro et al., 2016). The calculation and observation of the density of $C$. vulgaris were carried out using an Olympus binocular microscope with a magnification of $10 \times$ or $40 \times$ and with a hand tally counter counting tool. The calculation of the cell density of $C$. vulgaris was carried out during the culture activity for 7 days. The plankton calculations were carried out on four large hemocytometer boxes and the average cells per box were calculated (Gopal, 2004). The formula used according to the statement of Gopal (2004) is as follows:

Density (cell. $\left.\mathrm{mL}^{-1}\right)=\frac{\mathrm{nA}+\mathrm{nB}+\mathrm{nC}+\mathrm{nD}}{4} \times 10^{4}$

Information:

$\mathrm{nA}, \mathrm{nB}, \mathrm{nC}, \mathrm{nD} \quad$ : The number of phytoplankton cells in blocks $\mathrm{A}, \mathrm{B}, \mathrm{C}, \mathrm{D}$

4

: The number of boxes counted

Measurement of water quality parameters. Water quality was measured every day at 07.00 WIB (morning) for 7 days of culture activities, consisting of dissolved oxygen, $\mathrm{pH}$, transparency, temperature, nitrate, phosphate, and salinity. These parameters were chosen because it could affect the growth of the $C$. vulgaris. Water quality control needed to be done because the mass-scale culture in this study was carried out in an open place (outdoor) so that the environmental factors would affect the water quality. The results of water quality measurements can be seen in Table 1.

Statistical analysis. The research data were analyzed using MS. Excel 2016 software. The multiple linear regression test was used to determine the effect of water quality parameters on the growth of $C$. vulgaris by data processing using the SPSS 16.0 application.

\section{RESULTS AND DISCUSSION}

Growth of $\boldsymbol{C}$. vulgaris. The cell densities value from the $1^{\text {st }}$ day to the $3^{\text {rd }}$ day of culture activity shows a slow increase in tank 1 and tank 2 because there is still an adjustment or adaptation to the new culture media (Arsad et al., 2020a). Meanwhile, on the $4^{\text {th }}$ day of culture activity the value increases rapidly in tank 1 and tank 2 , and the $4^{\text {th }}$ day itself is an exponential phase so that harvesting could be carried out. This statement is in accordance with the opinion of Creswell (2010) stating that after adjusting themselves, the algae cells divide rapidly so that the population will increase, which takes place on the $4^{\text {th }}$ day or so of culture activity. The increased of cell population at the beginning of culture is due to the abundance of nutrients available in the culture media so that the C. vulgaris did cell division repeatedly. The cell density began to decline on the $5^{\text {th }}$ day of culture activity, and will slowly decline again on the $6^{\text {th }}$ and $7^{\text {th }}$ day of culture activity. The cause of the decrease in cell density value is the decrease in nutrients and fed competition on C. vulgaris. The results of the calculation of cell density in tank 1 and tank 2 have different values, in which the value of cell density is higher in tank 2 because the hose used in tank 2 during the strain spreading is covered with cloth at the end of the hose to help filter the litter so that it does not get inside the culture tank, so 
what escapes is only the desired phytoplankton. Meanwhile, the strain spreading that is carried out in tank 1 does not use a cloth at the end of the hose, so it allows a lot of litter or dirt to get into the culture tank, which makes the presence of phytoplankton lower or the density value smaller. The density value obtained in mass scale culture activities is higher than the density value for semi-mass and lab scale culture because the media used are different with different uses. The graph of the density and growth phase of $C$. vulgaris can be seen in Figure 3 and Figure 4.

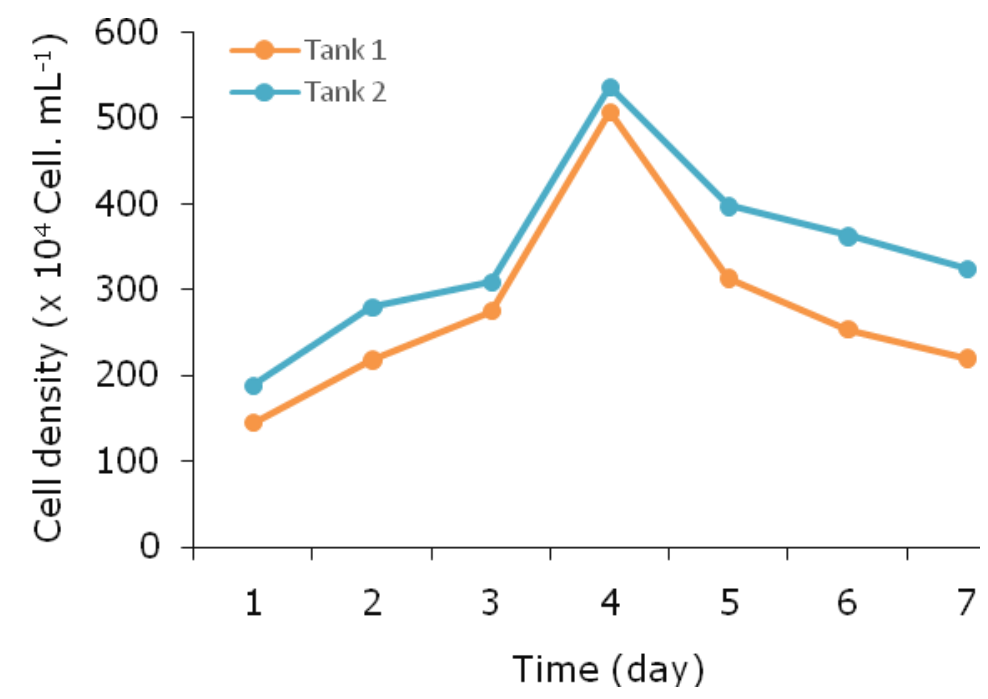

Figure 3. Graph of the calculation results of cell density of C. vulgaris in mass scale.

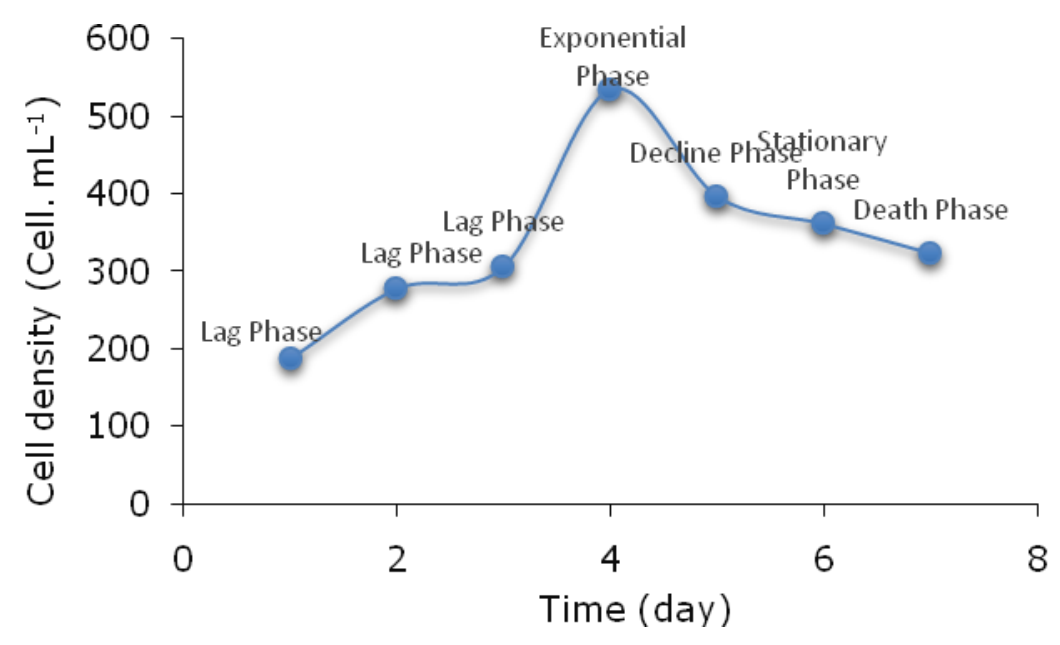

Figure 4. The growth curve of $C$. vulgaris during experiment.

\section{Water Quality Parameters}

Dissolved oxygen. Dissolved oxygen content is a reflection of the photosynthetic activity of phytoplankton biomass (Choudhury \& Pal, 2010). The results of dissolved oxygen measurement in tank 1 and tank 2 for 7 days of culture range from $4.82-6.97 \mathrm{mg}$. $\mathrm{L}^{-1}$. The dissolved oxygen value is ideal for meeting the needs of aquatic organisms for dissolved oxygen. This statement is in accordance with the opinion of Effendi (2003) stating that waters intended for fisheries purposes should have oxygen levels not $<5 \mathrm{mg}$. $\mathrm{L}^{-1}$, and if the dissolved oxygen level is $<4 \mathrm{mg}$. $\mathrm{L}^{-1}$, it will have an adverse effect on almost all aquatic organisms. The value of dissolved oxygen in tank 1 and tank 2 experiences an increase until the $4^{\text {th }}$ day of culture activity due to the increasing number or density of C. vulgaris, which produce dissolved 
oxygen through the photosynthesis process. The dissolved oxygen value will affect the metabolism of $C$. vulgaris. This statement is in accordance with the opinion of Prasetio et al. (2016) stating that dissolved oxygen can affect the physiology and metabolism of plankton. The dissolved oxygen value in the two tanks begins to decline from the $5^{\text {th }}$ to the $7^{\text {th }}$ day of culture activity due to the decrease in the density of $C$. vulgaris, so the dissolved oxygen produced through the photosynthesis process would also decrease. The average value of dissolved oxygen in tank 2 is higher than that in tank 1 because the density value of $C$. vulgaris is higher in tank 2.

Power of Hydrogen (pH). The results of pH measurements in tank 1 and tank 2 for 7 days of culture activity show a range of 8.2-9.1. This value is considered good or optimum to support the growth of $C$. vulgaris. This statement is in accordance with the opinion of Aprilliyanti et al. (2016) stating that the optimum pH limit value for growth of Chlorella sp. ranges from 8.25 to 9.82. The $\mathrm{pH}$ value in tank 1 and tank 2 increases every day until the $4^{\text {th }}$ day, but then it tends to decrease on the $5^{\text {th }}$ day to the $7^{\text {th }}$ day of culture activity. The increase in $\mathrm{pH}$ value is due to the increase in the number or density of $C$. vulgaris, which utilize carbon dioxide for the photosynthesis process so that there is less carbon dioxide in the water. This causes the $\mathrm{pH}$ value to rise or become alkaline because the $\mathrm{pH}$ value is inversely proportional with the presence of carbon dioxide in the water. One of the reasons for the decrease in $\mathrm{pH}$ value is the decrease in the density of $C$. vulgaris. The average $\mathrm{pH}$ value obtained in tank 2 is greater than that in tank 1 . This difference is due to the higher density of $C$. vulgaris in tank 2 so that carbon dioxide in the water decreases because it is used more, and the dissolved oxygen content is higher, which makes the $\mathrm{pH}$ of the water become alkaline.

Transparency. The results of transparency measurements obtained in tank 1 and tank 2 for 7 days of culture activity range from $20-45 \mathrm{~cm}$. This value is considered good for supporting the growth of C. vulgaris. This statement is in accordance with the opinion of Junda (2018) and Boyd (1990) stating that the optimum transparency value for plankton growth is $20-50 \mathrm{~cm}$. The transparency value in both tanks decreases from the $1^{\text {st }}$ day to the $4^{\text {th }}$ day of culture activity due to the increasing density value of $C$. vulgaris which could inhibit sunlight into the water. The brightness value experiences another decrease on the $5^{\text {th }}$ day to the $7^{\text {th }}$ day of culture activity because the culture tank is contaminated by Rotifers ( $B$. plicatilis), which increases the density of the culture tank and causes lower intensity of sunlight entering the water. The average transparency value obtained in tank 2 is smaller than that in tank 1 . This difference is due to the higher density value of $C$. vulgaris which causes the darker color of the water in the culture tank so that the intensity of sunlight that could penetrate the water occurs at shallower depths, which then causes the transparency value in tank 2 to be smaller.

Temperature. The results of temperature measurements in tank 1 and tank 2 obtained for 7 days of culture activity range from $26.8-28.2^{\circ} \mathrm{C}$. This value is considered good for supporting the growth of $C$. vulgaris. This statement is in accordance with the opinion of Nurlaili et al. (2015) and Arsad et al. (2020b) stating that the optimal temperature in microalgae culture is generally between $25-35^{\circ} \mathrm{C}$. The temperature value increases on the $1^{\text {st }}$ day to the $4^{\text {th }}$ day of culture activity due to the increase in the density value, so the heat generated from the metabolic process of the organism can increase the water temperature. The temperature value decreases on the $5^{\text {th }}$ to the $7^{\text {th }}$ day of culture activity due to the decreasing density value. The average temperature value obtained in tank 2 is greater than that in tank 1 . This difference is due to the fact that tank 2 has a higher density of $C$. vulgaris, so the heat generated from the metabolic processes of the organism is also higher, which leads to an increase in water temperature.

Nitrate. The results of nitrate measurements in tank 1 and tank 2 for 7 days of culture activity show a range of $0.10-0.50 \mathrm{mg} . \mathrm{L}^{-1}$. This value is considered good or optimum to support the growth of C. vulgaris. This statement is in accordance with the opinion of Wardoyo (1982) stating that the optimal nitrate level for phytoplankton growth is $0.1-3.5 \mathrm{mg}^{-1} \mathrm{~L}^{-1}$, and nitrate will be a limiting factor for the growth of Chlorella sp. when the nitrate level reaches $1.8 \mathrm{mg} . \mathrm{L}^{-1}$ or above and is below $0.02 \mathrm{mg}$. $\mathrm{L}^{-1}$. The nitrate value in the culture tanks only 
decreases until the $2^{\text {nd }}$ day and did not change until the $7^{\text {th }}$ day. This value only shows the range value, and will be more accurate if measured using modern measuring instruments such as a spectrophotometer. Nitrate content in the culture tanks decreases because it is used by $C$. vulgaris as a nitrogen source for growth, but the presence of nitrate will never run out.

Phosphate. The results of phosphate measurements in tank 1 and tank 2 for 7 days of culture activity show a range of $0.75-2 \mathrm{mg}$. $\mathrm{L}^{-1}$. This value is considered good or optimum to support the growth of $C$. vulgaris. This statement is in accordance with the research of Rumanti, et al. (2014) stating that the optimal phosphate content for phytoplankton growth is in the range of 0.27-5.51 mg. $\mathrm{L}^{-1}$, while the phosphate content of less than $0.02 \mathrm{mg}$. $\mathrm{L}^{-1}$ will be a limiting factor. The phosphate measurement results in the culture tanks decrease every day. This decrease is due to the utilization of phosphate by the $C$. vulgaris as a nutrient for their growth. The phosphate values in the two culture tanks measured using a phosphate test kit show the same value, and may have different values when measured using a measuring instrument that has higher accuracy such as a spectrophotometer because the density value of $C$. vulgaris in both tanks shows a different value.

Salinity. The results of salinity measurements in tank 1 and tank 2 for 7 days of culture activity show a range of 30-39 ppt. This value is considered good for supporting the growth of C. vulgaris. This statement is in accordance with the opinion of Rachmawati (2019) stating that salinity with a value of $30 \mathrm{ppt}$ is a very good level for the growth of $C$. vulgaris and has the ability to withstand high salinity in the case that it can tolerate salinity between 33-40 ppt. The salinity value in the two tanks tends to increase from the $1^{\text {st }}$ day to the $4^{\text {th }}$ day of culture activity due to the increasing density value of $C$. vulgaris which is able to excrete salts from its cell metabolism. The energy produced by phytoplankton will have an impact on the evaporation of the culture media, so the salinity value of the media will increase (Widayat et al., 2018). The salinity value in both tanks increases on the $6^{\text {th }}$ and the $7^{\text {th }}$ day of culture activity due to the absence of additional water in the culture tanks and the evaporation process. The average salinity value in tank 2 is higher than that in tank 1 because tank 2 has a higher density value of $C$. vulgaris than does tank 1 .

Table 1. The Water Quality Value in the Cultivation Tanks

\begin{tabular}{|c|c|c|c|c|c|}
\hline \multirow[b]{2}{*}{$\begin{array}{l}\text { Water Quality } \\
\text { Parameter }\end{array}$} & \multicolumn{4}{|c|}{ Value } & \multirow[b]{2}{*}{$\begin{array}{l}\text { Quality standard value } \\
\text { (Reference) }\end{array}$} \\
\hline & $\begin{array}{c}\text { Tank } 1 \\
\text { (Seawater/ } \\
\text { Cultivation } \\
\text { Media) }\end{array}$ & $\begin{array}{c}\text { Tank } 2 \\
\text { (Seawater/ } \\
\text { Cultivation } \\
\text { Media) }\end{array}$ & $\begin{array}{c}\text { Tank } 1 \\
\text { ( } 7 \text { days of } \\
\text { cultivation } \\
\text { activity) }\end{array}$ & $\begin{array}{c}\text { Tank } 2 \\
\text { ( } 7 \text { days of } \\
\text { cultivation } \\
\text { activity) }\end{array}$ & \\
\hline $\begin{array}{l}\text { Dissolved } \\
\text { Oxygen } \\
\left(\mathrm{mg} . \mathrm{L}^{-1}\right)\end{array}$ & 5.29 & 5.28 & $4.82-6.23$ & $5.11-6.97$ & $\begin{array}{l}>4 \mathrm{~m} \\
\text { (Effendi, 2003) }\end{array}$ \\
\hline $\mathrm{pH}$ & 7.9 & 7.9 & $8.2-9$ & $8.3-9.1$ & $\begin{array}{l}8.25-9.82 \\
\text { (Aprilliyanti et al., 2016) }\end{array}$ \\
\hline $\begin{array}{l}\text { Transparency } \\
(\mathrm{cm})\end{array}$ & $100 \%$ & $100 \%$ & $25-45$ & $20-43$ & $\begin{array}{l}20-50 \\
\text { (Junda, } 2018 \text { \& Boyd, } \\
1990 \text { ) }\end{array}$ \\
\hline $\begin{array}{l}\text { Temperature } \\
\left({ }^{\circ} \mathrm{C}\right)\end{array}$ & 28.3 & 28.2 & $26.8-28$ & $27.1-28.2$ & $\begin{array}{l}25-35 \\
\text { (Nurlaili et al., 2015) }\end{array}$ \\
\hline $\begin{array}{l}\text { Nitrate } \\
\left(\mathrm{mg} \cdot \mathrm{L}^{-1}\right)\end{array}$ & 0.10 & 0.10 & $0.10-0.50$ & $0.10-0.50$ & $\begin{array}{l}0.1-3.5 \\
\text { (Wardoyo, 1982) }\end{array}$ \\
\hline $\begin{array}{l}\text { Phosphate } \\
\left(\mathrm{mg} . \mathrm{L}^{-1}\right)\end{array}$ & 0.25 & 0.25 & $0.75-2$ & $0.75-2$ & $\begin{array}{l}0.27-5.51 \\
\text { (Rumanti et al., 014) }\end{array}$ \\
\hline $\begin{array}{l}\text { Salinity } \\
\text { (ppt) }\end{array}$ & 35 & 35 & $30-37$ & $33-39$ & $\begin{array}{l}\text { 33-40 } \\
\text { (Rachmawati, 2019) }\end{array}$ \\
\hline
\end{tabular}


Effect of water quality parameters on the growth of $\boldsymbol{C}$. vulgaris. The effect of water quality on the growth of $C$. vulgaris is analyzed using multiple linear regression analysis. From the results of the analysis, it is obtained the correlation coefficient $(r)$ of $0.978(a=0.05)$. This value indicates that the relationship of dissolved oxygen, $\mathrm{pH}$, transparency, temperature, nitrate, phosphate, and salinity is simultaneously very strong towards the growth of $C$. vulgaris, which means that overall water quality greatly affects the growth of $C$. vulgaris. Based on the multiple linear regression analysis (Table 2), water quality parameters simultaneously have a very strong effect on the growth of $C$. vulgaris with a percentage of dissolved oxygen of $46.32 \%, \mathrm{pH}$ of $25.08 \%$, transparency of $11.48 \%$, temperature of $9.92 \%$, nitrate of $3.43 \%$, phosphate of $2.09 \%$, and salinity of $1.68 \%$.

Table 2. Score of SE and SR

\begin{tabular}{lcc}
\hline \multicolumn{1}{c}{ Parameter } & Score of SE & Score of SR \\
\hline Dissolved oxygen (X1) & 44.30 & 46.32 \\
$\mathrm{pH}(\mathrm{X} 2)$ & 23.99 & 25.08 \\
Transparency (X3) & 10.98 & 11.48 \\
Temperature (X4) & 9.49 & 9.92 \\
Nitrate (X5) & 3.28 & 3.43 \\
Phosphate (X6) & 2.00 & 2.09 \\
Salinity (X7) & 1.61 & 1.68 \\
\hline R Square/Total & 95.63 & 100 \\
\hline Effective Contribution (SE) and Relative Contribution (SR)
\end{tabular}

\section{CONCLUSION}

The conclusion obtained from the present research on the management of mass-scale cultivation of $C$. vulgaris is that water quality parameters simultaneously have a very strong influence on the growth of $C$. vulgaris with a percentage of dissolved oxygen of $46.32 \%, \mathrm{pH}$ of $25.08 \%$, transparency of $11.48 \%$, temperature of $9.92 \%$, nitrate of $3.43 \%$, phosphate of $2.09 \%$, and salinity of $1.68 \%$. The main differences between mass, semi-mass, and laboratory scale microalgae cultivation are the culture media used, the amount of fertilizer required, the number of microalgae produced, and the utilization.

\section{ACKNOWLDGEMENT}

Deep gratitude is expressed to the Technical Implementation Unit of Freshwater and Brackish Water Aquaculture, Situbondo, for the facilitation of this research, and the article processing and proofread was supported by AquaRES research group grant 2020 No:1103.10/UN10.C10/PN/2020 funded by LPPM Universitas Brawijaya.

\section{REFERENCES}

Aprilliyanti, S., Soeprobowati, T. R., \& Yulianto, B. (2016). The relationship between the abundance of Chlorella sp and the water quality of semi-mass scale culture in BBPBAP Jepara [Indonesian]. Jurnal IImu Lingkungan, 14(2), 77-81. https://www.neliti.com/publications/101625/hubungan-kemelimpahan-chlorella-spdengan-kualitas-lingkungan-perairan-pada-skal.

Arsad, S., Stavrakakis C., Turpin V., Rossa P., Risjani Y., Sari L. A., Prasetiya F. S., Mouget J. L. (2019). Optimization of diatom Haslea ostrearia cultivation in different mediums and 
nutrients. IOP Conference Series: Earth and Environmental Science, 236 (012044), 11 p. https://iopscience.iop.org/article/10.1088/1755-1315/236/1/012044

Arsad, S., Sari, LA., Suherman, SP., Cahyani, D., Nadhira, T., Yulinda, EN., Musa, M., Lusiana, ED., Prasetiya, FS. (2020a). Utilization of tofu wastewater as Chlorella pyrenoidosa growth medium. $\quad$ AACL Bioflux, 13(5), 2878-2885. http://www.bioflux.com.ro/docs/2020.2878-2885.pdf

Arsad, S., Kholifah, S. N., Prabawati, E., Sari, L. A., Kadim, M. K., Kilawati, Y. (2020b). Effect of mercury on growth of several microalgae. Asian Journal of water, environment, and pollution, 17(3), 13-17. https://content.iospress.com/articles/asian-journal-of-waterenvironment-and-pollution/ajw200029

Becker, W. (1994). Mikroalgae: Biotechnology and Microbiology. Cambridge University Press (112-146).

https://books.google.co.id/books?hl=id\&lr=\&id=KAKx4I7NWEYC\&oi=fnd\&pg=PP299\&dq $=$ Microalgae: + Biotechnology + and + Microbiology\&ots=037tSNOVdN\&sig =JebVxAWPB4z

D7okEopCkIDSBko\&redir_esc $=y \# v=$ onepage $\& q=$ Microalgae $\% 3 \mathrm{~A} \% 20$ Biotechnology $\% 20$ and $\% 20$ Microbiology\&f $=$ false

Boroh, R., Litaay, M., Umar, M. R., \& Ambeng. (2019). Growth of Chlorella sp. combinated with several culture media [Indonesian]. Jurnal Biologi Makassar, 4(2), 129-137. https://journal.unhas.ac.id/index.php/bioma/article/view/6759.

Boyd, C. E. (1990). Water Quality in Ponds for Aquaculture. Experiment Station Alabama (482 hlm). https://agris.fao.org/agris-search/search.do?recordID=US19930090347.

Chia, M. A., Lombardi, A. T., \& Melao, M. D. G. G. (2013). Growth and biochemical composition of Chlorella vulgaris in different growth media. Anais da Academia Brasileira de Ciencias, 85(4), 1427-1438. https://www.scielo.br/pdf/aabc/v85n4/0001-3765-aabc00-00-6613.pdf

Choudhury, A. K., \& Pal, R. (2010). Phytoplankton and nutrient dynamics of shallow coastal stations at Bay of Bengal, Eastern Indian coast. Aquatic Ecology, 44, 55-71. https://doi.org/10.1007/s10452-009-9252-9

Creswell, L. (2010). Phytoplankton culture for aquaculture feed. Southern Regional Aquaculture Center, 1-13. http://fisheries.tamu.edu/files/2013/09/SRAC-PublicationNo.-5004-Phytoplankton-Culture-for-Aquaculture-Feed.pdf

Daliry, S., Hallajisani, A., Roshandeh, J. M., Nouri, H., \& Golzary, A. (2017). Investigation of optimal condition for Chlorella vulgaris microalgae growth. Global Journal of Environmental Science and Management, 3(2), 217-230. https://www.sid.ir/en/journal/ViewPaper.aspx?id=525847

Effendi, H. (2003). Assessment of water quality for aquatic resources and environment management [Indonesian]. Kanisius.

Gopal, K. (2004). Fundamentals of Water and Waste Water. APH Publishing Corporation. https://books.google.co.id/books/about/Fundamentals_of_Water_and_Waste_Water.ht ml?id=WUubF-teR10C\&redir_esc $=y$

Hadiyanto \& Azim, M. (2012). Microalgae food source and future energy [Indonesian]. Semarang: UPT UNDIP Press. http://eprints.undip.ac.id/48607/1/Buku_Mikroalga__B5.pdf

Junda, M. (2018). Development of intensive shrimp farming, Litopenaeus vannamei in landbased ponds: production and management. Journal of Physics: Conference Series, 1028, 1-6. https://iopscience.iop.org/article/10.1088/1742-6596/1028/1/012020/meta

Kandi, I. W. (2018). Culture technique of Chlorella vulgaris phytoplankton in the laboratory scale as natural food for Daphnia sp. at aquaculture technology development center (BPTPB) Cangkringan, Sleman, Yogyakarta [Indonesian]. Universitas Airlangga Repository. http://repository.unair.ac.id/78502/

Maresi, S. R. P., Priyanti., \& Yunita, E. (2015). Phytoplankton as bioindicator of water saprobic in Bulakan Situ Kota Tangerang [Indonesian]. Al-Kauniyah Jurnal Biologi, 8(2), 113122. http://journal.uinjkt.ac.id/index.php/kauniyah/article/view/2697

Novianti, T., Zainuri, M., \& Widowati, I. (2017). Study of the growth of microalgae Chlorella vulgaris cultivated based on different light sources [Indonesian]. MANGIFERA EDU: Jurnal Biologi and Pendidikan Biologi, 1(2), 1-8. https://scholar.google.co.id/scholar?hl=id\&as_sdt=0\%2C5\&q=Studi+tentang + pertumb 
uhan+mikroalga +Chlorella+vulgaris+yang+dikultivasi+berdasarkan+sumber+cahaya+ yang+berbeda\&btnG $=$

Nurlaili, F. R., Hendrawan, Y., \& Nugroho, W. A. (2015). The effect of the addition of bacteria (Azospirillum sp.) doses on the abundance of microalgae populations (Chlorella sp.) in biogas liquid waste culture media (after anaerobic process) [Indonesian]. Jurnal Keteknikan Pertanian Tropis dan Biosistem, 3(2), 121-126. https://jkptb.ub.ac.id/index.php/jkptb/article/view/265

Persada, A. Y., Navia, Z. I., Saputri, A., Putri, K. A., \& Fajar, B. A. (2019). Phytoplankton species inventory at Pulau Pusong, Langsa, Aceh [Indonesian]. Elkawine: Journal of Islamic Science and Technology, 57-75. https://core.ac.uk/download/pdf/228448775.pdf

Prasetio, H., Purwiyanto, A. I. S., \& Agussalim, A. 2016. Analysis of heavy metal lead (pb) and copper (cu) in plankton at the Banyuasin estuary south Sumatera province [Indonesian]. MASPARI JOURNAL, 8(2), 73-82. https://www.researchgate.net/publication/308982355_analisis_logam_berat_timbal_pb _dan_tembaga_cu_dalam_plankton_di_muara_banyuasin_provinsi_sumatera_selatan_a nalysis_of_heavy_metal_lead_pb_and_copper_cu_in_plankton_at_the_banyuasin_estua ry_south_sumat

Prayogo, I., \& Arifin, M. (2015). Technique of natural feed culture Chlorella sp. and Rotifera sp. on mass scale and management of natural feeding of cantang grouper larvae [Indonesian]. Samakia: Jurnal IImu Perikanan, 6(2), 125-134. https://core.ac.uk/download/pdf/276635732.pdf

Rachmawati, A. 2019. Utilization of Chlorella sp. as bioacccumulator Cadmium metal (Cd) [Indonesian]. [Script study program S-1 Biologi, Fakulty of Science and technology, Universitas Islam Negeri Maulana Malik Ibrahim Malang]. Electronic Theses Universitas Islam Negeri Maulana Malik Ibrahim Malang. http://etheses.uin-malang.ac.id/17295/

Romdhane, F. H., Zheng, X., Jaouen, P., Pruvost, J., Grizeau, D., Croue, J. P., \& Bourseau, P. (2013). The culture of Chlorella vulgaris in a recycled supernatant: effects on biomass production and medium quality. Bioresource Technology, 132, 285-292. https://doi.org/10.1016/j.biortech.2013.01.025

Rumanti, M., Rudiyanti, S., \& Suparjo, M. N. (2014). The relationship between nitrate and phosphate content with the abundance of phytoplankton in the Bremi River, Pekalongan Regency [Indonesian]. Diponegoro Journal of Maquares, 3(1), 168-176. https://ejournal3.undip.ac.id/index.php/maquares/article/view/4434

Salgueiro, J. L., Perez, L., Maceiras, R., Sanchez, A., \& Cancela, A. (2016). Bioremediation of wastewater using Chlorella vulgaris microalgae: phosphorus and organic matter. International Journal of Environmental Research, 10(3), 465-470. https://ijer.ut.ac.ir/article_58766.html

Salman, J. M., Hadi, S. J., \& Mutaer, A. A. (2013). Spatial and temporal distribution of phytoplankton and some related physical and chemical properties in Al-Abasia River (Euphrates), Iraq. International Journal of Geology, Earth \& Environmental Sciences, 3(3), 155-169. http://www.uobabylon.edu.iq/eprints/publication_1_8546_416.pdf

Wardoyo, S. T. H. (1982). Water quality management for environmental resources management study center [Indonesian]. Institut Pertanian Bogor: Bogor.

Widayat., Philia, J., \& Wibisono, J. (2018). Cultivation of microalgae Chlorella sp on fresh water and waste water of tofu industry. E3S Web of Conferences, 31, 04009. https://www.e3s conferences.org/articles/e3sconf/abs/2018/06/e3sconf_icenis2018_04009/e3sconf_icen is2018_04009.html

Winder, M., \& Sommer, U. (2012). Phytoplankton response to a changing climate. Hydrobiologia, 698, 5-16. https://doi.org/10.1007/978-94-007-5790-5_2 